\title{
الاحتياجات التدريبية لمديري المدارس الأجنبية في مدينة عمّان
}

\section{هشام خليل عوده الزيديين}

مقدمة:

بدور ها تتمي المهار ات و المقدرات الأساسية للطلبة من خلال تطبيــق معــايير البـــر امج الأجنبية، وتتــــلى وز ارة التربيـــة و التعلــيم

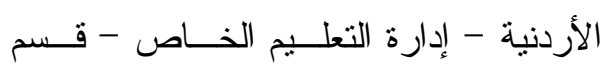

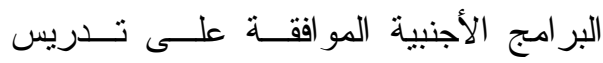

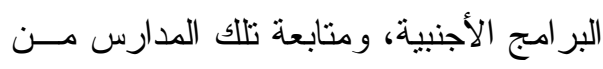

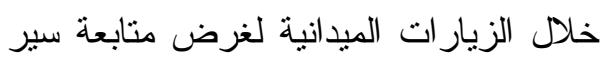

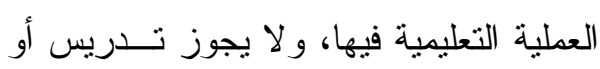
الإعلان عن أي برنامج من البرامج الأجنبية

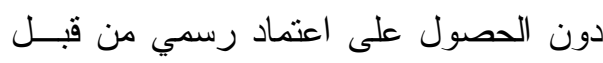

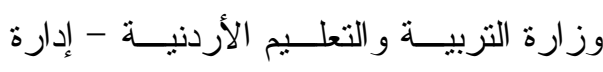

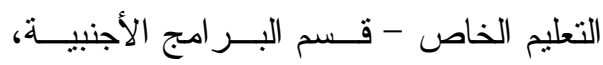
و هيئات الاعتماد المعنية لكل برنامج تعليمي أجنبي (وز ارة التربية و التعليم، V V. Y). ولما كان موضوع الحاجات التدريبية

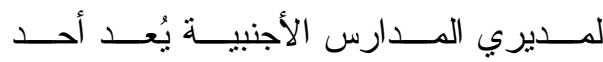
الموضوعات المهمة في التعليم الأجنبي فـي لئي

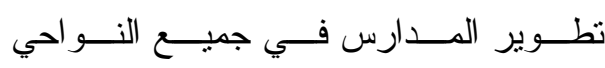
الأكاديمية، فقد إحتل هذا النوع من التتميــة

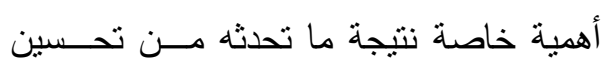

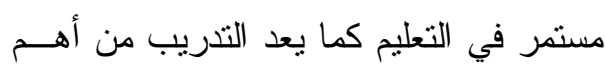
المقومات الأساسية الفعالة في تطــــير أداء مديري المدارس وتحسينه.
حقق التعليم فـــي المملكـــة الأردنيـــة

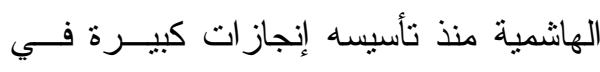
جميع مناطق المملكة من تطــــير للمنـــاهج

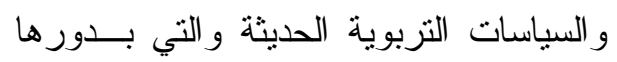

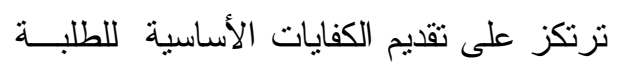

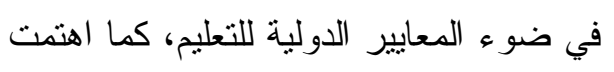

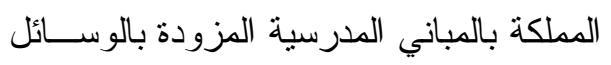

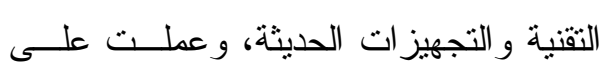

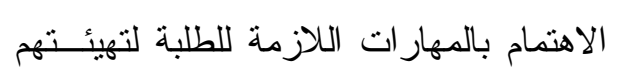

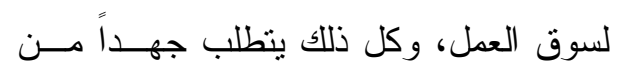
المدرسة و القائمين عليها وخاصة مع ظهون لئطور

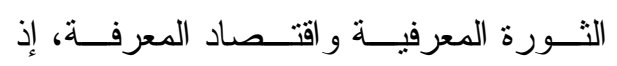
تطورت النظرة إلى المدرسة بـشكل كبيــر

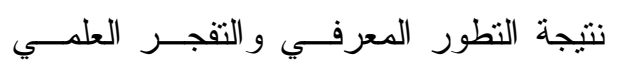
و أصبح دور المدرسة أشمل من ذي قبل من فن

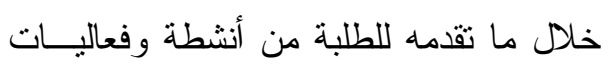

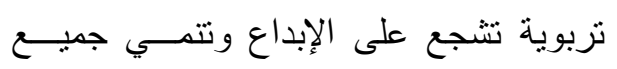
المهار ات المطلوبة للمستقبل. وحينها لا بد من التحـدث عـن دور

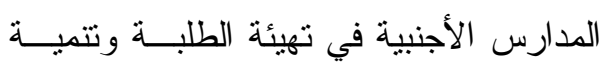
مهار اتهم ومقدر اتهم اللازمة لمرحلة مستقبلية

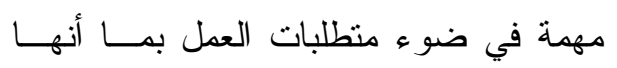

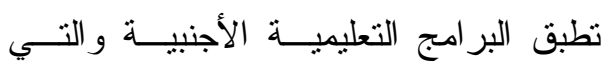




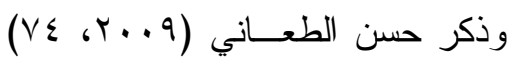

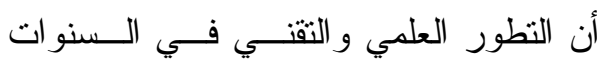

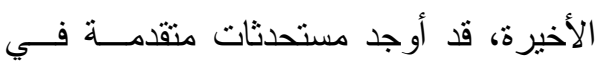

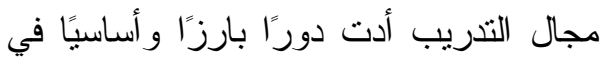

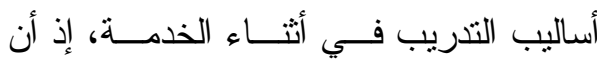
الأساليب التقليدية غير قادرة علـــى الإيفــاء بمنطلبات العصر الحالي.

ويقصد بالتتمية بـشكل عـام أنهــا:

تطوير المهارات و المقدرات الفردية اللازمة

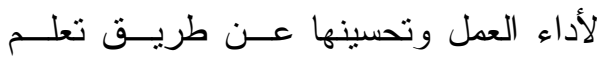

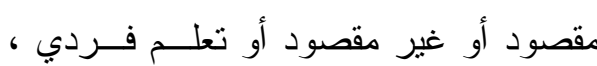

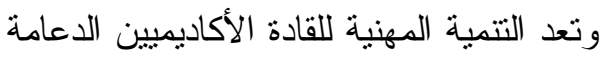
الأساسية التي يمكن مــن خلالهــــا إكـــابهم

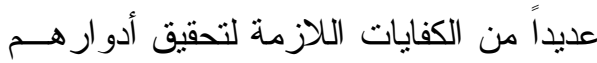

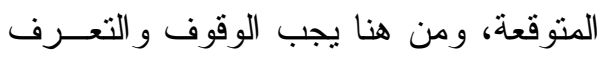

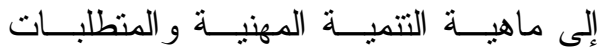

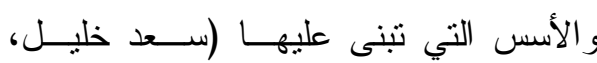

. (rq) 6 . . . q

وكل ذلك يشير إلى ضرورة الاهنمام بالتدريب و التتمية لمديري المدارس الأجنبية و التي تهدف إلى تطوير مقدر اتهم وكفايــاتهم

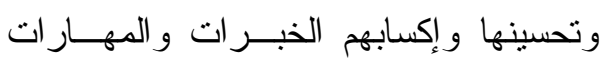
اللازمة لتطوير الأداء، ونظر أ لما لمــديري

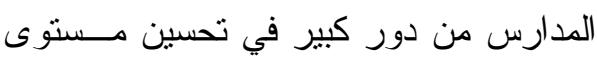
العملية التعليمية وتطور ها، فقد وجد الباحث

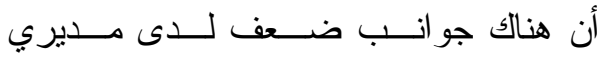

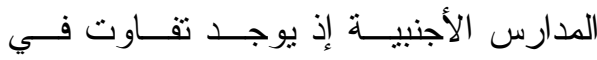

تعد الأحتياجــات المهنيــة لمــديري

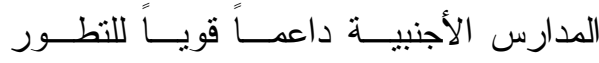

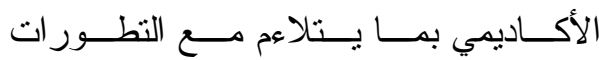

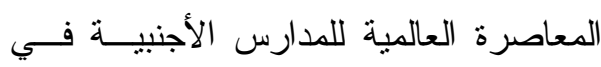

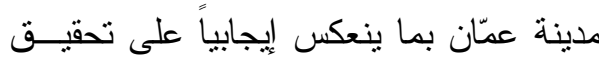

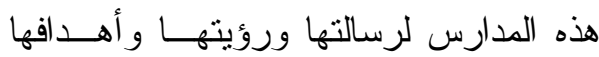

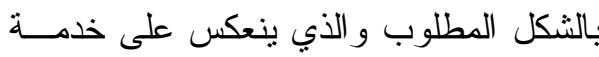

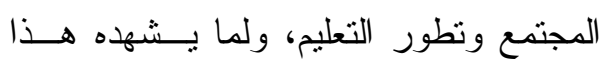
العصر من ثــورة متـسـار عة فـي مجـــال التكنولوجيا و الاتصـال و المعلومــات و التــي هورهي

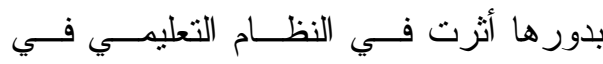

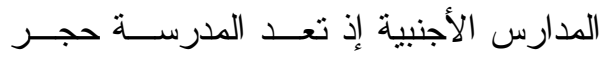

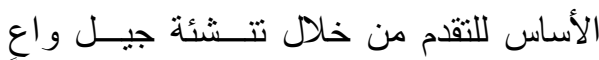
فكان لا بد من إيجاد مديرين مؤهلين مدربين

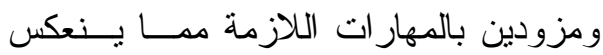
على تطوير التعليم في المدارس الأجنبية. إن التغييرات المستمرة و المتـسارعة التي يشهدها العالم تقرض على المؤسـسات و المنظمات المختلفة إحداث تطوير وتغييــر مؤسسي باستمر ار لكي تستطيع العمل علـى لـى

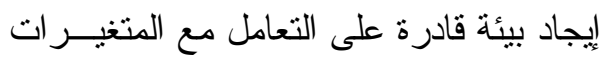
المحيطة لأجل تتفيذ خططها وبر امجها بشكل

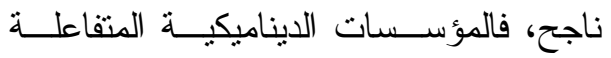
مع محيطها الخارجي هـي التـي تحسـدث التغيير وتحقـق الأهـــاف وتــتـكن مـنـ

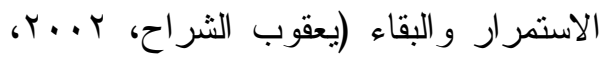
. (or 
تفاوت في المقدر ات و المهار ات و المعلومات

الأكاديمية المتعلقة بتطوير أدائهم. و اســتنادًا

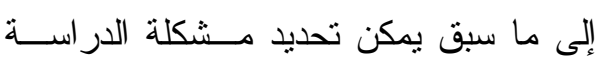

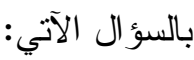

-ما الاحتياجات التدريبية لمديري المــدارس

$$
\text { الأجنبية في مدينة عمّان ؟ }
$$

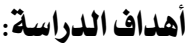

هدفت هذه الدر اسة إلى اعداد تصور

مقترح لتعرف الاحتياجات التدريبية لمديري المدارس الأجنبية (البرنــامج الــدولي) فــي لــي مدينة عمّان. - مدان.

أهمية الدراسة:

تتبع أهمية هذه الدر اسة من النقاط الآتية: - يؤمل من هذه الدر اسة أن نثري البحـــث العلمي في مجال الاحتياجات التـريبيــة

$$
\text { لمديري المدارس. }
$$

- يؤمل أن تفيد نتائج هذه الدر اسة الجهات المعنية فـي وز ارة التزبيــة و التعلــيم الأردنيــة - قــسم البـــر امج الأجنبيــــة

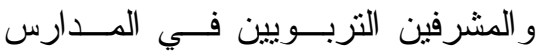
الأجنبية في التدريب و التطوير •

- يؤمل أن تفيد نتائج هذه الدر اسة مديري المدارس الأجنبية فـي تعــرفهم علـى يـى

$$
\text { تطوير الأداء. }
$$

منهج الدراسة:

نظرًا لطبيعة الدر اســـة و المعلومـــات المطلوبة للإجابة عن أسئلتها وتحقيق أهدافها
المقدر ات و المهار ات و المعلومات الأكاديمية المتعلقة في تطوير أداء مـــديري المـــدارس الأجنبية، وللتغلب علــى جوانــب القــصور ورفع كفاءة مديري المدارس وتحسين أدائهم من خلال الوسائل والأساليب التي نتاســب

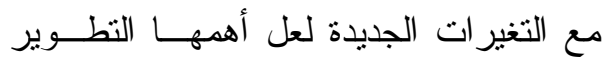
المستمر وورشات العمل في أثناء الخدمــة، و هكذا جاءت فكرة هذه الدراسة التي نزكــز حول إعداد تــصور مقتـر ح للاحتياجـات التدريبية لمديري المدارس الأجنبية في مدينة

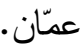

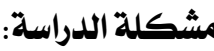

يؤدي مديرو المدارس الأجنبيـــة دوراً مهماً في تحقيق أهداف المؤسسة على أرض الواقع من خلال البر امج والأنشطة التعليمية المختلفة، كما يثرف المديرون علــى تتفيــذ الأنشطة ومتابعة العاملين للتأكد من تحقيــق

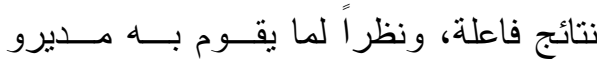
المدارس الأجنبية مــن تحقيــق مخرجـات

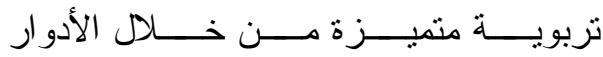

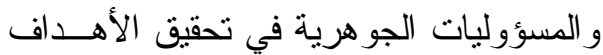
التربوية، ومن خلال اللقاءات و المـــتثمر ات وورش العمل التي تقوم بها وزر اة التربيــة و التعليم الأردنية مع بعض مديري المدارس الأجنبية والقائمين عليها في المملكة الأردنية الهاشمية، وجد الباحث أن هنــالك جوانــبـ ضعف لدى مديري هذه المدارس تمنلت في 
الدراسات السابقة ذات الصلة:

تضمن هذا الجزء من الفـصل الأول

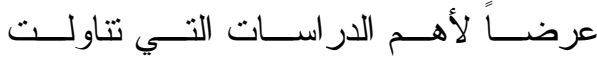

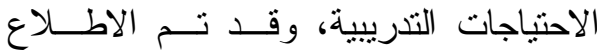

و الاستفادة من عدد لا بأس به من الدراسات

التربوية المرتبطة بمجال الدر اسة.

بــتم عــرض الدر اســـات العربيـــة

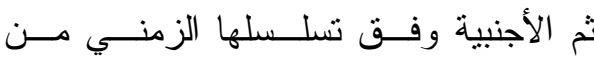

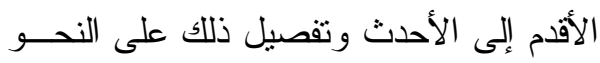

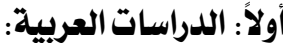

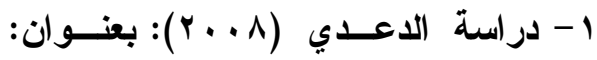

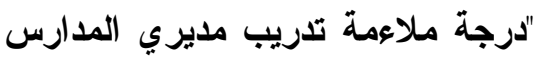

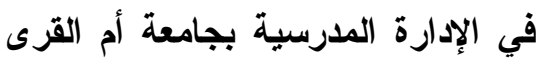

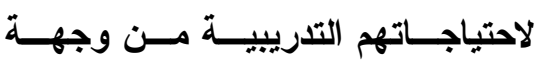

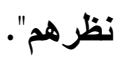

هدفت هذه الدراسة إلى التعرف إلـى

درجة ملاعمة تدريب مديري المدارس فـي

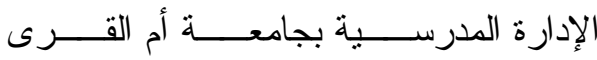

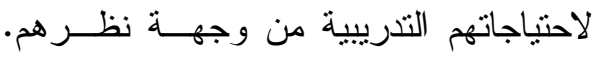

ومعرفة ما إذا كانت هناك فروق ذات دلالة

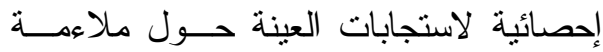

تدريب مديري المــارس تعـزى للمؤهــل وسنوات الخبـرة بالعهـلـل الإداري وعــد

الــدورات فـي مجــال الإدارة المدرســية.

وأستخدم المنهج الوصفي، وصنمّمت استبانة

شملت سبعة محاور هي: خطـــة البرنــامج
أُعتمد مــنهج البحــث الوصــفي بوصــفه

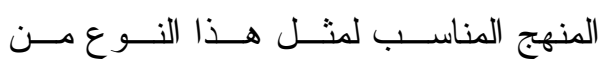

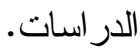

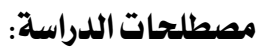

اثـــتملت الدر اســــة الحاليــة علــى

المصطلحات الآتية التي عُرُّفــت مفاهيميــاً و اجر ائياً: • الاحتياجات التدريبية:

لقد تعددت التعريفات التـي تتاولــت

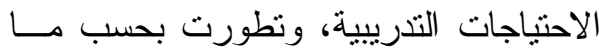
فرضته طبيعــة العـصر مــن تغييــرات، ومستجدات فقد عرفهـا الـشريف (T . .T، 19 (1) بأنها"الفرق أو النقص أو الفجوة بــين

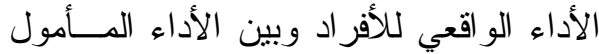

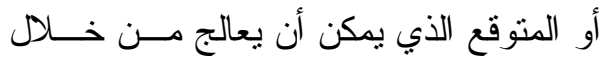

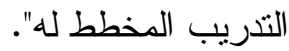

ويتبنى الباحث تعريفـــه للاحتباجــات

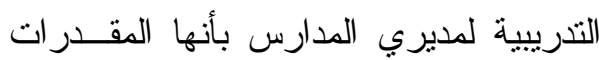

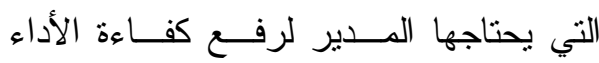
وفاعلية المدرسة.

$$
\text { • المدارس الأجنبية: }
$$

هي منشآت تعليمية غيــر حكوميــة

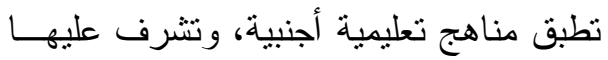

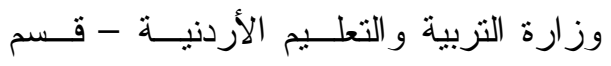
البرامج الأجنبية (وزارة التزبية و التعلــيم ، ولئه $\cdot(r \cdot 11$ 
وقد أُستخدمت استبانة نم تطويرها لتحقيــق أهداف الدراسة، وقد أظهرت النتائج: - أن اتجاهات مديري المدارس الثانويـــة الحكومية و المشرفين التربويين في إقليم

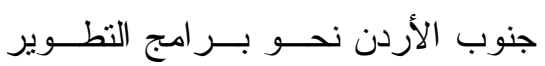

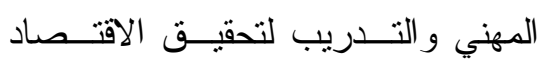

$$
\text { المعرفي جاءت بدرجة مرتفعة. }
$$

- عدم وجود أثز ذي دلالة إحصائية يعزى بله مرنه

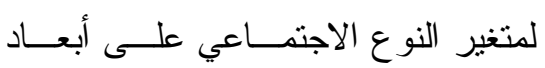

$$
\text { الدر اسة. }
$$

-وجود فروق ذات دلالة إحصائية تعزى لمتغير الخبرة ولصالح أصحاب الخبــرة الأكثر.

- وجود فروق ذات دلالة إحصائية تعزى الادر لمتغير الوظيفــة ولــصالح المـشرفين

$$
\text { التربوبين. }
$$

- وجود علاقة ذات دلالة إحصائية بـين

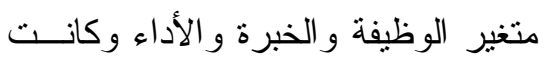

$$
\text { لصالح المشرفين التربوبين. }
$$

r- دراسة الـشهوان ( • ( + r): بعنــوان:

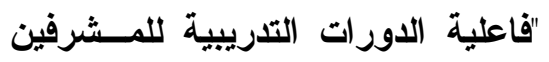
التربويين ومديري المدارس من وجهة

$$
\text { نظر المتدربين". }
$$

هدفت هذه الدراسة إلى التعرف إلـى

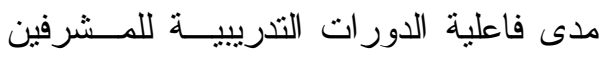

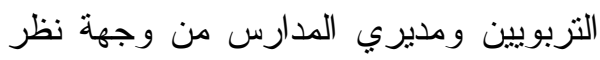

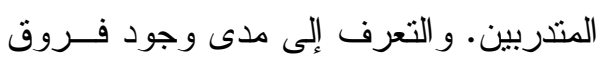

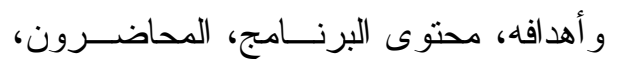

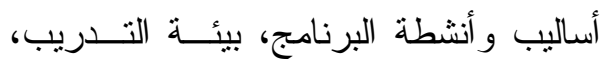
طرق القياس و التقـــويم، وبعـض كض كفايــات

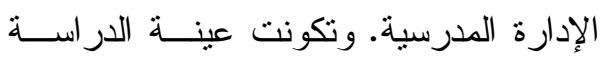

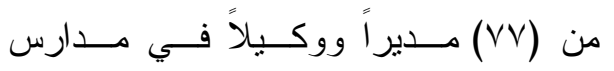
مكة المكرمة. وكانت النتائج علـى النحسـو الآتي: - أن درجة الملاعمة في جميع المحسـاور جاءت متوسطة حسب استجابات أفــر اد

$$
\text { العينة. }
$$

- لا توجد فروق ذات دلالة إحصائية حول درجة ملاعمة البرامج التدريبية تعـزى دله التهاته

$$
\text { للمؤهل العلمي. }
$$

- توجد فروق دالة إحصائياً مع ســنوات هل الخبرة الأطول و عدد الدور ات الأكثر .

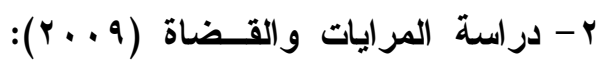
بعنوان: "اتجاهات مــدراء المــدارس وله

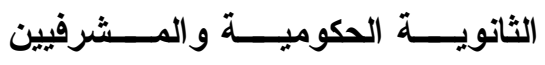
التربويين في إقليم جنوب الأردن نحسـو

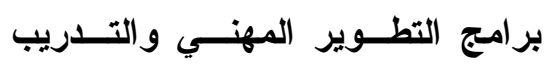
لتحقيق الاثتصاد المعرفي". هدفت هذه الدراســة إلـى تعــرف

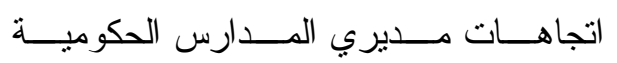
و المشرفين التربويين في إقليم جنوب الأردن نحو برامج النطوير المهني و التدريب لتحقيق الاقتصاد المعرفي، وقد نم اختيار عينة طبقية عشو ائية بلغت (99 ) مديرًاً ومشرفاً تربوياً، 
ع - دراسة السـلمي (Y Y ب): بعنــوان: "الاحتياجات التدريبية لمديري المدارس" الإبتدائية بمدينة مكة المكرمة في ضوء منطلبات الإدارة الإكترونية".

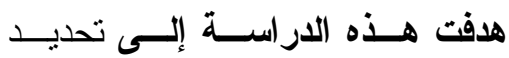
الاحتياجات التنديبيــة لمــديري المـــارس

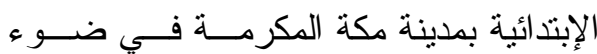

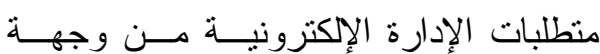
نظر هم. و التعرف إلى مدى وجـــود فــروق ذات دلالة إحصائية بين الاحتياجات التذريبية

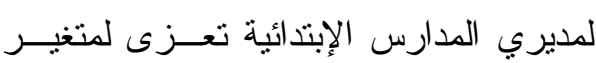

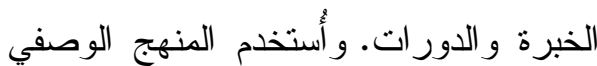
التحليلي، وصُمّت استبانة تضمنت خمسسة ولته

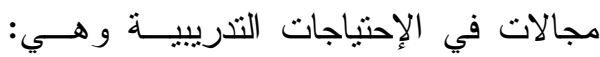

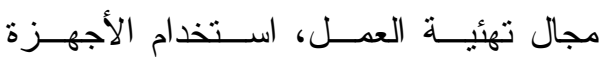

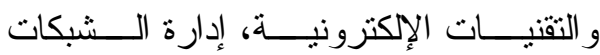
و المعلومـــات، حفــ المعلومــات الرقميـــة و استرجاعها، أمن المعلومات. وتكونت عينة

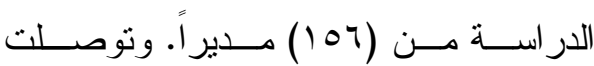

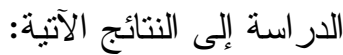

- أن أهم الاحتياجات التدريبية في ضـــو الته

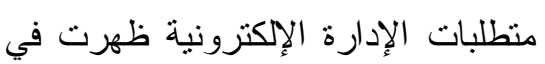

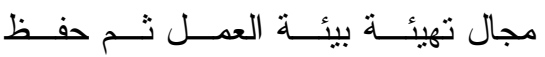
المعلومات و استرجاعها ثـم اســتخدام الأجهزة و الثقنيات الإلكترونية ثم أمسـن المعلومات ثم التدريب علــى الــشبكات وقو اعد البيانات.
ذات دلالة إحصائية بين متوسطات اســتجابة

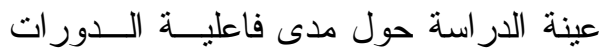
التدريبية للهـشرفين التربــويين ومــديري

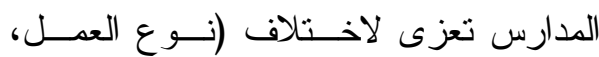

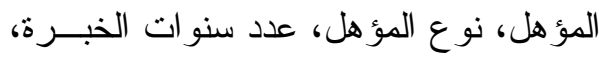

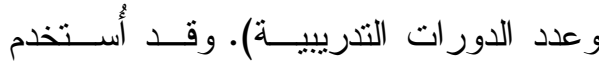

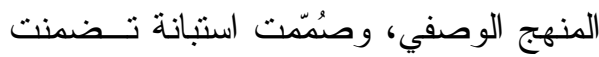
خمسة محاور هي: خطة البرنامج التدريبي، أساليب طرق التدريب، اتجاهات المـديرين التهن نحو المتثربين، اتجاهات المتــدربين نحــو البرنامج التدريبي، و أسلوب التقبــيم للــدورة التدريبية. وشملت العينة جميع المتخــرجين ولين

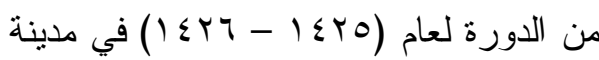

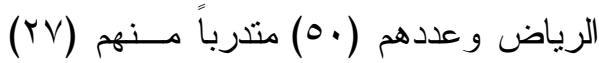

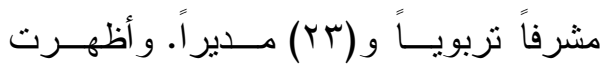

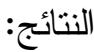
- أن الـــدور ات التنريبيـــــة للــــشرفين التربويين ومديري المدارس كانت لهـــا فاعلية في الملتحقين بها تركزت ما بين متوسطة، و عالية. - وجود فروق ذات دلالة إحصائية حسب وعبة نوع العمل تجاه فاعلية الدورات لصالح

$$
\text { المشرفين. }
$$

- لا توجد فروق ذات دلالـــة إحـصـيائية تعزى للمؤهل، ونوع المؤهل، وسنو ات لترول

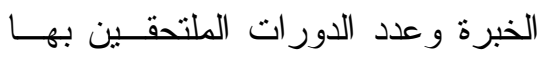
سابقاً. 
البر امج، تقويم البر امج. وطبقـــ الاســنبانة على عينة عشوائية شــملت (YV9) مــشرفاً تزبوياً. وتوصلت الدر اسة إلى النتائج الآتية: - أن درجة فاعلية بر امج أساليب النتميــة

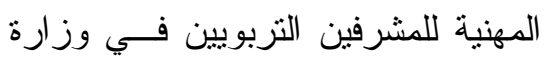
التربية و التعليم الأردنية من وجهة نظر لنرين

المشرفين التربويين كانت متوسطة. - وجود فروق ذات دلالة إحـصائية فـي

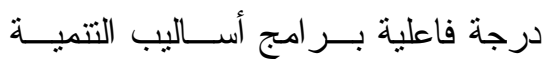

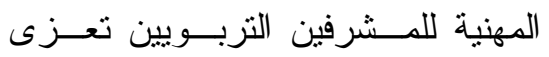

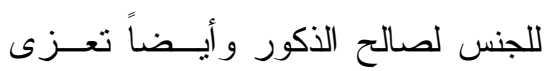

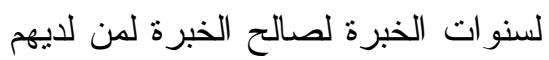

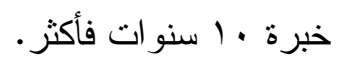

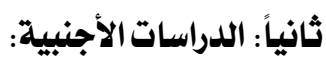

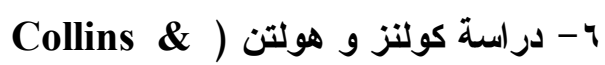

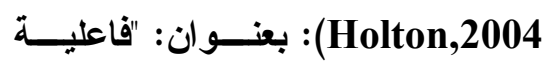

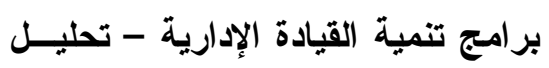
بعدي للار اسات من ץ ب 19 1 - 1 . . ץ". هدفت هذه الاراسة إلى تحليل درجة تطور الأداء و المعرفة والخبرة على مستوى لهاه الفرد أو الفريق أو المجموعة أو المـستوى وله التتظيمي في الدراسات المقدمة خلال القتـــرة

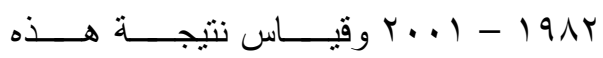
الدراسات وحجم تأثنير ها في تطوير القيــادة

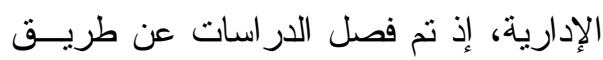

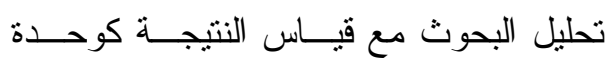
للتحليل، وطبقت الدر اسة على (r^) در اســـة
- عدم وجود فروق ذات دلالة إحــصائية

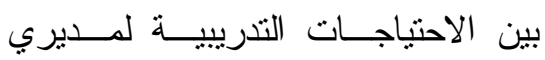

المدارس الإبتدائية بمدينة مكة المكرمسـة لئسة

في ضوء متطلبات الإدارة الإككترونيـــة

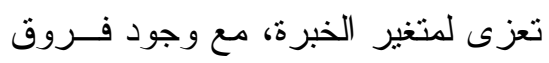

ذات دلالة إحصائية فــي مجــالي إدارة

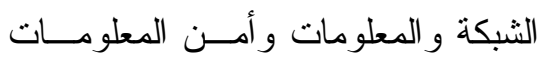

لصالح الحاصلين على أكثر من دورنين تدريبيتين.

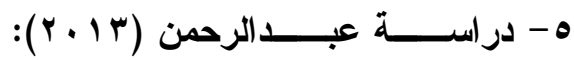

بعنوان: "درجة فاعلية أساليب برامج التنمية المهنية للمشرفين التربويين في وزارة التربية والتعليم الأردنيــة من وجهة نظر المشرفين التربويين". هدفت هذه الدراسة إلى قياس درجــة

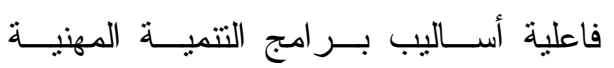

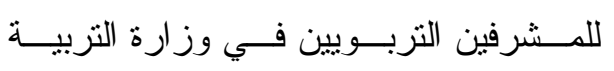

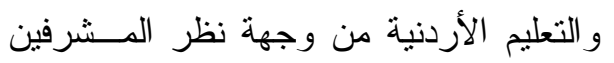

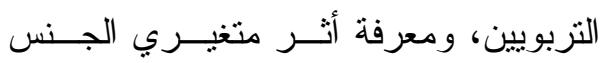
و الخبرة في متوسط استجابات أفر اد العينــة

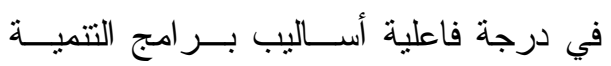

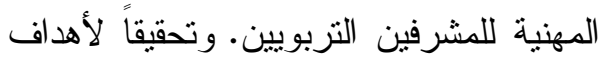

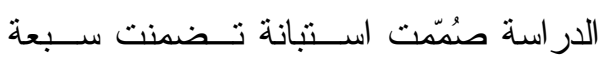
مجالات هي: خطط التتمية المهنية وبر امجها

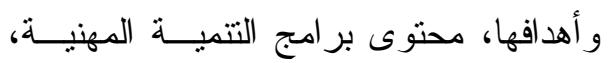

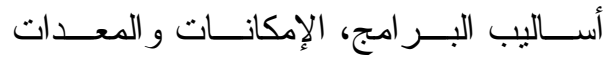

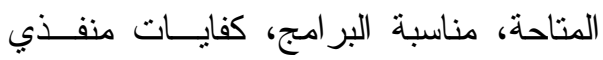


الدراسة، وهو الوصول إلى تصور مقتــرح

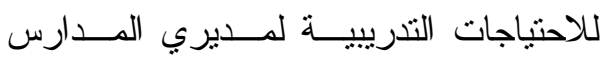

الأجنبية في مدينة عمّان ومن خلا اطلاع الهاع

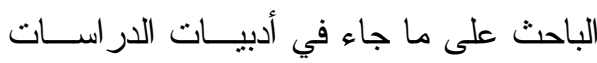

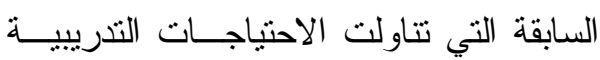

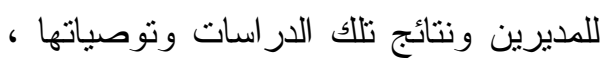

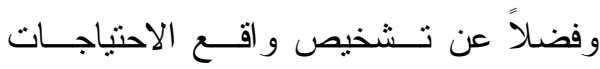

التدريبية لمديري المدارس الأجنبية في مدينة

عمّان، يتضمن هذا الفصل مجموعــة مــن

العناصر هي: فلسفة التصور المقترح، رؤية

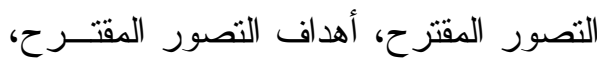

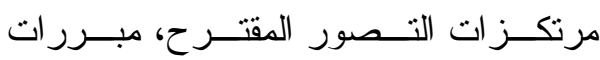

التصور المقتر ح ودو افعه، محتوى التـصور ملـر

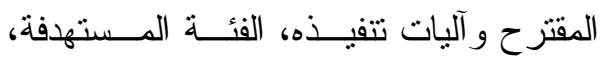

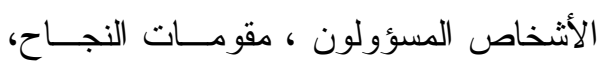

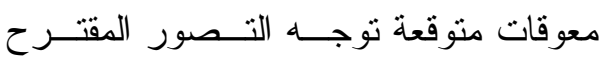

و آليات التغلب عليها، الثقويم.

أولاً: فلسفة التصور المقتزح:

اعتمد التصور المقتزح للاحتياجـات

التدريبية لمديري المدارس الأجنبية في مدينة

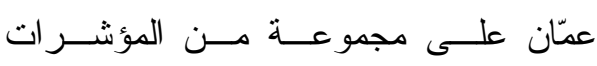

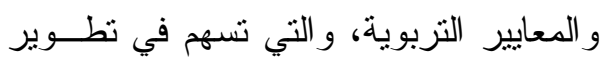
المنظومـــة التعليميـــة و التزبويـــة لمــديري المدارس الأجنبية في مدينة عمّان، وضــبط ولئ

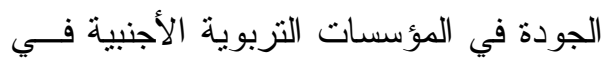

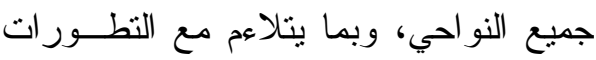

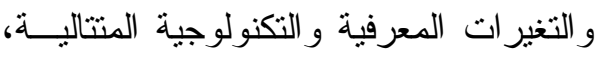

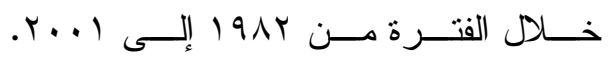

$$
\text { وأثنارت نتيجة الدر اسة إلى الآتي: }
$$

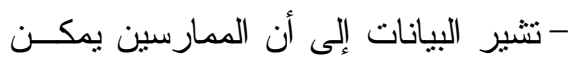

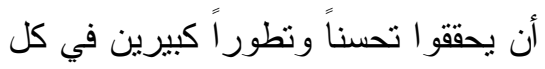

من المعرفة و المهار ات على حد ســـواء

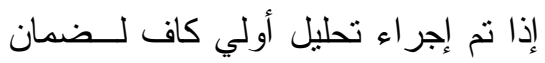

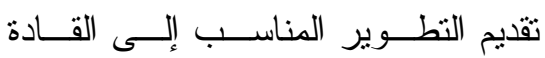

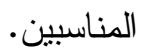

وبناءاً على ما نم الإطلاع عليه مسن

دراسات سابقة، و إثنارة الكثير من الدراسات

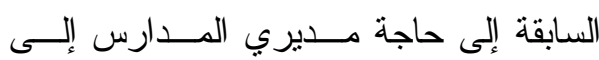

التدريب و التطوير ومن خلال عمل وخبــرة

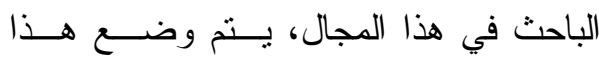

التصور المقتــرح للاحتياجــات التدريبيــة

لمديري المدارس الأجنبية في مدينة عمّان.

ترنكز المدارس الأجنبية فــي مدينــة

عمّان في صورتها على الصبغة العالمية بحثاً عن التميز و الجــودة و المنافـسة و والانفتـــاح الثقافي. ويُعد التدريب في المدارس الأجنبية

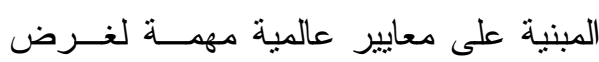

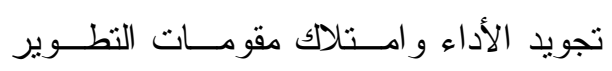

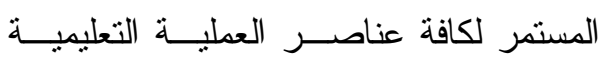
وخاصة العنصر البشري حيث إذ يُعد تأهيله

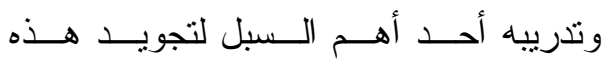

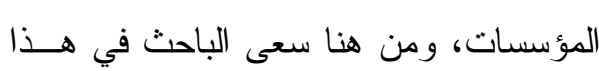

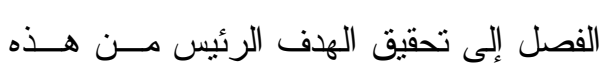


r- مساعدة المديرين في اتخاذ القــرارات

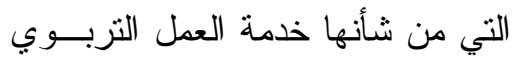

$$
\text { و الأكاديمي. }
$$

؟ - تقديم إطار عــام وشــامل لتـدريب

$$
\text { وتطوير المديرين. }
$$

0- تحديد بــر امج التـدريب للمـديرين

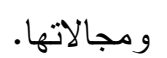

צ- نقديم بعض الاقتر احات و الرؤى فيما

يتعلق بير امج هدفها تدريب وتطـــــير

$$
\text { المديرين. }
$$

V- نشر ثقافة التدريب و التطوير داخـل

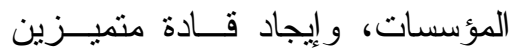

بالأداء قادرين علــى تحقيــق رؤيـــة

$$
\text { المؤسسة ورسالتها و أهد افها. }
$$

^- تحسين مخرجات التعليم لدعم أسواق العمل المحلية و العالمية.

$$
\text { رابعاً: مرتكزات التصور الققترح: }
$$

تم بناء التصور المقتــرح بالاســتناد إلــى مئس

$$
\text { المرتكز ات الرئيسة الآتية : }
$$

1- يُعد التغيير حقيقة حتمية وضــرورة

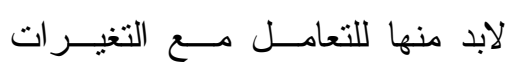

$$
\text { و التطور ات العصرية. }
$$

r- تشخيص الواقع الحالي للاحتياجـات

التدريبية لمديري المدارس الأجنبيــة

$$
\text { في مدينة عمّان. }
$$

و التفجر المعرفي في العصر الحالي. ويُعـد التصور المقترح فكرة جديدة مبنية على نتائج فعلية مبدانية من خبرات الماضي و الحاضر بتصور جديد تهدف إلى رؤية مستقبلية قابلة

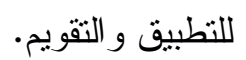

\section{ثانياً: رؤية التصور القترح:}

انطلق هذا التصور من أهمية التدريب

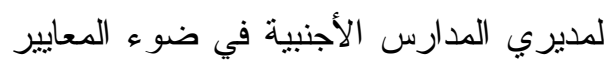

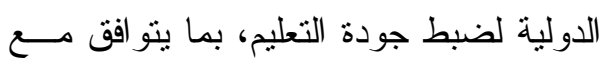

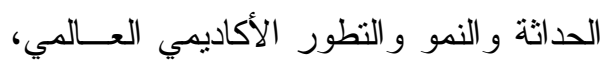
و التتافسية من خلال الخطط التشغيلية الفعلية لتدريب وتطوير مديري المدارس الأجنبيــة في مدينة عمّان. ثالثاً: أهداف التصور الثقتزح:

يهدف هذا التصور المقترح لتـدريب

ولتطوير مديري المدارس الأجنبية في مدينة عمّان ما ينعكس إيجاباً على تحسين الأداء

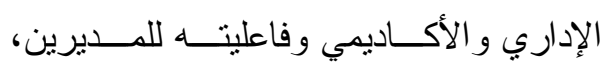

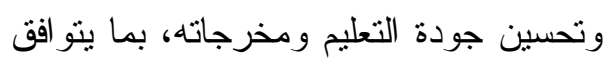

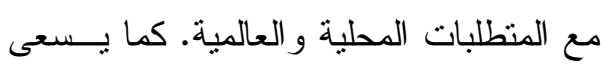

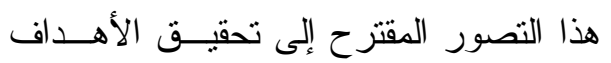
الآتية: - مالية

ا- إعداد مــديري المـــدارس الأجنبيــة وتأهيلهم لتحقيق أهداف المؤسسة.

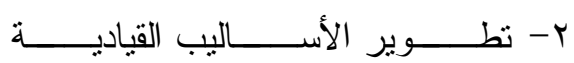
و الإثر افية. 
ץ- التغير ات و المستجدات في تأهيل القادة

$$
\text { التزبويين وتدريبهر. }
$$

r- القصور في البرامج التنريبية لتطوير مديري المدارس الأجنبية في مدينــة عمّان.

ـ - رغبة كثير من المؤسسات التربويـــة في مواكبة التغيرات التي حصلت في في لعني

$$
\text { التعليم. }
$$

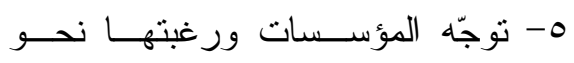

الحصول على الاعتمــاد الأكــاديمي

$$
\text { العالمي. }
$$

7- الـــشروط المتعلقــــة بــــالتز اخيص

$$
\text { وتجديدها. }
$$

- - مطالبة ثلاك المدارس بتحقيق الجودة

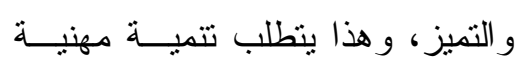

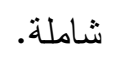

^- التغيرات التي حصلت في المقــررات

الدر اسية العالمية في كافة المجــالات الفيرات

$$
\text { و أساليب تقويمها. }
$$

$$
\text { ب- المـشكلات التــي تعــوق التــدريب }
$$

ع - المقترحات التي من شأنها نطوير أداء

$$
\text { المديرين }
$$

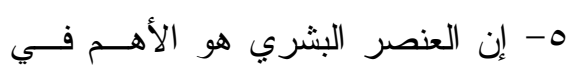

$$
\text { تحقيق أهداف المؤسسة وتميز ها. }
$$

\section{خامساً: مبررات التصور المقترح ودوافعه:}

هناك عديد من المبــررات والــدو افع مئع

للتصور المقترح لتدريب وتطـــوير مــديري

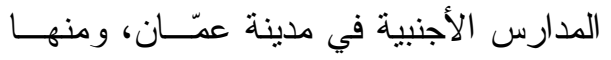
مبررات شخصية تتعلق بحاجة المديرين لها،

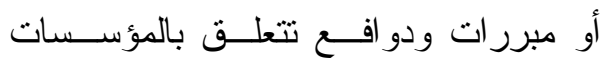
التزبوية تتعلق بالأهداف وتحقيقهـا، كـــللك

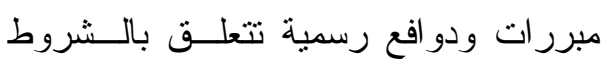
و القيود المفروضة على تلك المؤسسات مــن فئن قبل الدوائر الرسمية. ويمكن توضيح أبــرز هذه المبررات.

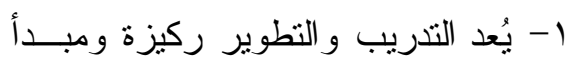

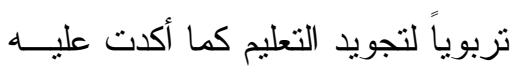
عديد مــن الدراســات و التوصــيات العلمية. 
سادساً: محتوى التصور المقترح وآليات تنفيذه:

يشتمل محتوى التصور المقترح على برامج وأنشطة لتدريب ونظوير مديري المدارس

الأجنبية في مدينة عمّان، ويمكن توضيح ذلك من خلال الجدول النالي:

\begin{tabular}{|c|}
\hline حزم البرامج والأشثطة التشرييية للمديرين \\
\hline أهمية الدو ام و الحفاظ عليه \\
\hline تشكيل علاقات إيجايية مع الزملاء - الطلاب - أولياء الأمور \\
\hline تفعيل مو اقع التو اصل الإداري للمدارس \\
\hline تقديم اقتز احات و أفكار تخدم العملية التعليمية فى المدارس \\
\hline أهمبة اللقاءات الرسمبة التى تخص المدارس داخلياً وخارجياً \\
\hline أهمية الإنجاز الإداري \\
\hline المشاركة الفعالة في الأنشطة الددرسية و أهميتها \\
\hline تطوير الخريطة الاستر اتيجية للمؤسسة \\
\hline دع الطلبة يقو دون الإدارة المتمركزة على الطلبة \\
\hline بطاقة الأداء المنو ازن كأداة إدارية \\
\hline إعادة النظر في التوجيه و الإثر اف على المعلم وتقييمه \\
\hline التخطيط لتعلم مختلف \\
\hline التخطيط للإبداع و المو هبة \\
\hline التغذية الر اجعة في التحسين المستمر \\
\hline مهار ات إدارة المشرو ع لإدارة العام الدر اسى \\
\hline أهمية احتباج المدارس و النظع المدرسية إلى خطة استر اتيجية \\
\hline بناء المجنمعات التعليمية من خلال العلاقات المدرسبة المتنبة \\
\hline أهمية عو امل جودة النظام \\
\hline قياس أداء القادة و المدرسين باستخدام الأهداف الذكية ومؤشر ات الأداء \\
\hline بطاقة النتائج كأداة للقيادة \\
\hline الطرق و الأساليب الحديثة في التدريس \\
\hline مهار ات إدارة النقاش و الحو ار بين المعلم /ة و الطلبة \\
\hline استر اتيجيات التعلم النشط \\
\hline بر امج تتبع الحافلات ونظويرها \\
\hline بناء خطة مجدولة لصيانة مر افق المدرسة \\
\hline إعداد جداول دورية لمتابعة مر افق المدرسة \\
\hline مهار ات التعلم الذاتى لدى الطلبة \\
\hline تطوير قاعدة بيانات المدرسة وتحديثها \\
\hline تتمية مهار ات التحفيز و الإبداع لدى الطلبة \\
\hline استخد ام التكنولوجيا ودمجها بالتعليم \\
\hline إدارة وقت الحصة بكفاءة وفاعلية \\
\hline
\end{tabular}




\begin{tabular}{|c|}
\hline حزم البر امج و الأشطة التدريبية للمديرين \\
\hline التخطيط للارس بمنهجية علمية و اضحة \\
\hline استخد ام استر اتيجيات التعلم بما يتناسب وطبيعة الدرس \\
\hline ربط أهداف المادة و المو اد الأخرى \\
\hline ضبط الوقت و إدارته بكفاءة \\
\hline الالتز ام بأخلاقيات المهنة وقيمها \\
\hline تعزيز الخبرات السابقة \\
\hline ربط ما تعلمة الطلبة في حياتهم \\
\hline التعلم المرئي \\
\hline ربط مخرجات التعلم و التقييم \\
\hline الأنو اع الرئيسة للمناقنشة الصفية في التعليم و التعلم \\
\hline استقطاب الكفاءات التعليمية المميزة \\
\hline تزجمة الخطة الأكاديمية إلى عمل على الو اقع \\
\hline استر اتيجيات تخصيص المو ازنات وتوزيعها بعدالة \\
\hline التغذية الر اجعة وزيادة الفاعلية \\
\hline استخدام الخدمات المدرسية لتحسن الأداء \\
\hline نظام تقييم المعلم الفعال \\
\hline حزم البر امج و الأنشطة التنريبية للديرين \\
\hline خطة السلامة و الأمن \\
\hline أدو ات الثقييم قونها وفاعليتها \\
\hline استبانات المسح و الغرض منها \\
\hline الدعم الفنى \\
\hline بر امج التعلم المهني ضمن نطاق العمل للعاملين \\
\hline توفير المو ارد لدعم عملية التعليم و التعلم \\
\hline نماذج الأداء و الممارسات المهنية \\
\hline سياسات النوظيف و الاحنياج \\
\hline استثمار المو ارد البشرية و المادية لزيادة فاعلية المؤسسة \\
\hline المصادر وسهولة الوصول لها وعلاقتها بتلبية احتباجات الطلبة \\
\hline
\end{tabular}

\section{سابعاً الفئة المستهدفة:}

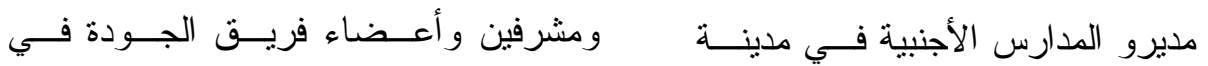

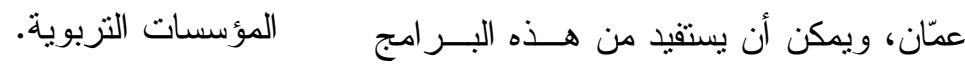

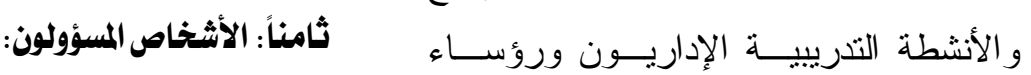

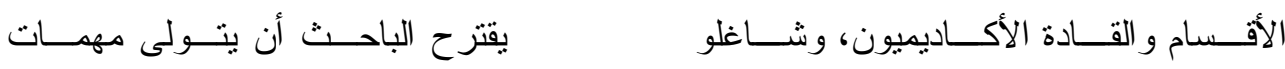

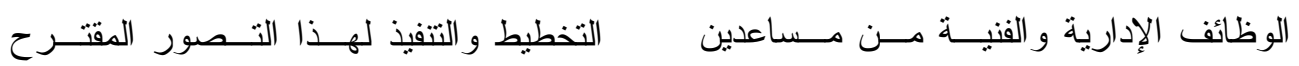




$$
\begin{aligned}
& \text { r- البناء النتظيمي النشاركي في السلطة } \\
& \text { المبني على الأنظمة و اللوائح المحددة }
\end{aligned}
$$

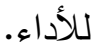

$$
\begin{aligned}
& \text { r- البناء التنظيمي المبني على اتصالات } \\
& \text { مفتوحة وخطط علمية واضحة. } \\
& \text { ع- البناء التنظيمي المبني على نشر نقافة } \\
& \text { المؤسسة في التحسين المستمر . }
\end{aligned}
$$

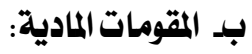

$$
\begin{aligned}
& \text { وتتمثل في تسخير الإمكانات و الــدعم } \\
& \text { المادي، وتخصيص ميز انيات مسنقلة لغرض الان } \\
& \text { تدريب وتطوير المديرين، وتتظــيم تبــادل } \\
& \text { الخبر ات بين المؤسسات التربويـــة المحليـــة } \\
& \text { و الدولية من خلال عمل منظم محكـــوم فـي لـي }
\end{aligned}
$$

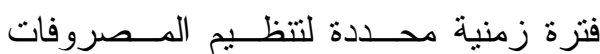

$$
\begin{aligned}
& \text { و الإنفاق، مما بساعد المؤسسة في اســنتمار }
\end{aligned}
$$

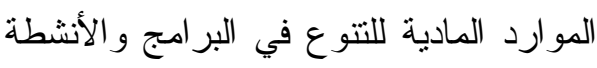

$$
\begin{aligned}
& \text { التدريبية المقدمة للمديرين وحسب الاحتياج. } \\
& \text { جـ القومات الشخصية: } \\
& \text { تشكل المقومات البشرية فــي تــوفير } \\
& \text { الهيئة الإدارية المدربة مـن المتخصـصين } \\
& \text { و أصحاب الكفاءات العالية ومن لهم خبرة في الئل }
\end{aligned}
$$

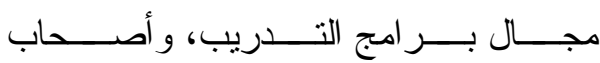

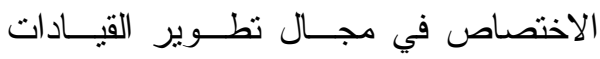

$$
\begin{aligned}
& \text { التزبوية، وعلـى أن بــتم تقـيمهم بــشكل } \\
& \text { سنوي. } \\
& \text { عاثراً: معوقات متوقعة تواجــهـ التـصور } \\
& \text { المقترح و آليات التظلب عليها: } \\
& \text { مر اكز تدريب مستقلة متخصصة في التدريب } \\
& \text { و التطوير، و أعضاء من العـاملين بهيئـات } \\
& \text { تربوية وتعليمية عالمية من أصحاب الكفــاءة } \\
& \text { و التدريب العالي. }
\end{aligned}
$$

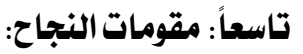

$$
\begin{aligned}
& \text { يعتمد نجاح تطبيق التصور المقتـرح } \\
& \text { لتدريب وتطوير مديري المدارس الأجنبيـــة } \\
& \text { في مدينة عمّان على تو افر مجموعــة مــن } \\
& \text { الإمكانات التتظيمية، و المادية، و الثخــصية } \\
& \text { التي تقود إلى نجاح وتحقيق التصور المقترح } \\
& \text { لأهدافه، ويمكن توضيح هــــه الإمكانيــات }
\end{aligned}
$$

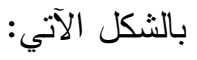

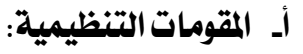




$$
\begin{aligned}
& \text { الأسرب و المجتمعي من خلال تـــوفير } \\
& \text { بعض من الاحتياجات الأسرية. }
\end{aligned}
$$

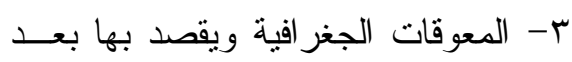

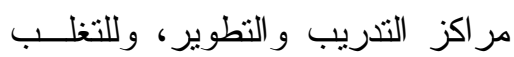

$$
\begin{aligned}
& \text { على ذلك ثقوم المؤسسة بتحمل كافـــة } \\
& \text { النفقات ووسائل التتقل من و إلى مكان }
\end{aligned}
$$

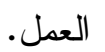

$$
\begin{aligned}
& \text { الحادي عشر: التقويم: } \\
& \text { تشير كثير من الدراسات إلى ضرورة } \\
& \text { تقويم الفائدة وقياس العائد و التعرف إلى نقاط } \\
& \text { القوة والضعف لما لها دور مهم وكبير فـي وني }
\end{aligned}
$$

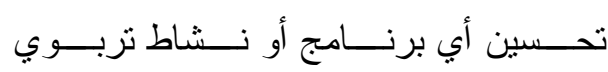

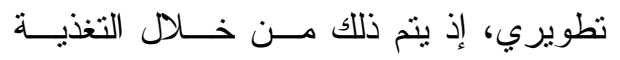

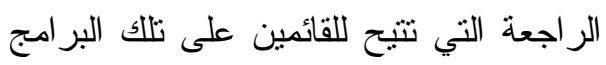

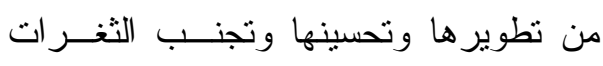

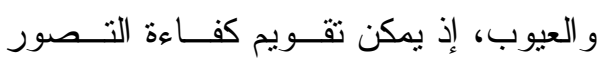

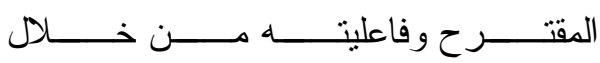

$$
\begin{aligned}
& \text { الآتي: } \\
& 1 \text { - يقوم فريق التخريب و التطوير بعمليــة }
\end{aligned}
$$

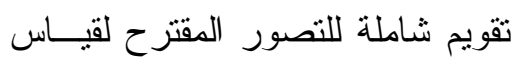

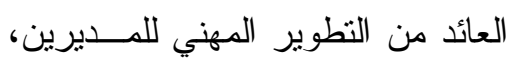

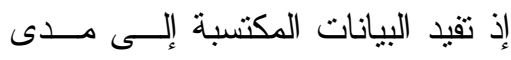

$$
\begin{aligned}
& \text { الفائدة التي حصل عليها المديرون. } \\
& \text { r- تطبيق ما تم التـريب عليه في البيئـــة }
\end{aligned}
$$

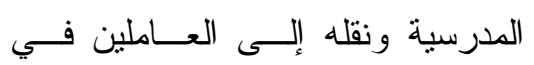

$$
\begin{aligned}
& \text { المؤسسسة ومتابعتهم في تتفيذها ، ويتم }
\end{aligned}
$$

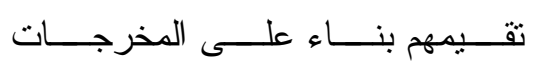

$$
\begin{aligned}
& \text { نظراً لسرعة التغيرات التكنولوجيــة }
\end{aligned}
$$

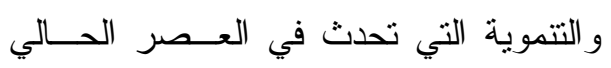

$$
\begin{aligned}
& \text { يو اجه النطور و التحسين و النمو المهني فــي } \\
& \text { المؤسسات التربوية صعوبات في مو اكبة نلك ولك ولكين }
\end{aligned}
$$

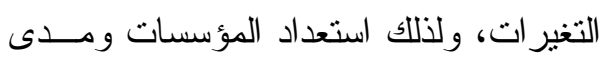

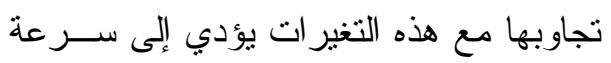

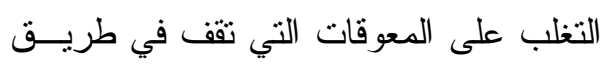

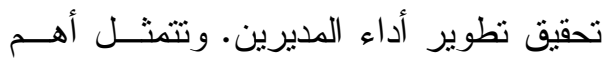

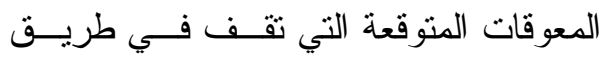

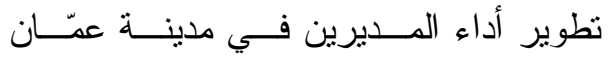

$$
\begin{aligned}
& \text { بالآتي: }
\end{aligned}
$$

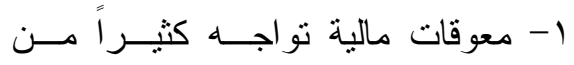

$$
\begin{aligned}
& \text { المديرين مع أصـــاب المؤسـسـات } \\
& \text { التربوية، و عدم وجــود مخصــصـات } \\
& \text { وحو افز مالية كافية لتدريب المديرين }
\end{aligned}
$$

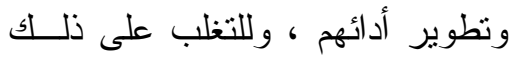

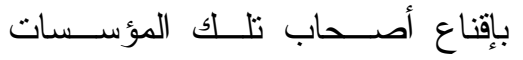

$$
\begin{aligned}
& \text { وملآكها بأهمية تخــــيص ميز انيــة }
\end{aligned}
$$

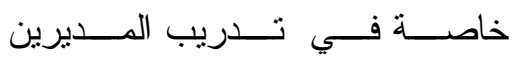

$$
\begin{aligned}
& \text { وتطوير هم و إلحاقهم بالبر امج التدريبية } \\
& \text { المهنية الحديثة التي مــن شــــنهأنها أن } \\
& \text { تعود بالفائدة على فاعلية المؤسـسها } \\
& \text { و أدائها. } \\
& \text { Y- عدم رغبــة كثيــر مــن المــديرين } \\
& \text { بالتطوير و التحسين نظر اً لانــشغالهم }
\end{aligned}
$$

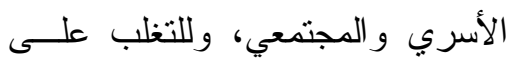

$$
\begin{aligned}
& \text { ذلك نوفير ما من شأنه تخفيف العبء ولمغن عاء }
\end{aligned}
$$


ماجستير غيــر منــشورة)،جامعـــة أم

القرى: مكة المكرمة، المملكة العربيــة السعودية.

ء. الثراح، يعقوب أحمد (Y . . ץ). التربية وأزمة التتمية البشرية، الرياض: مكتب التربية العربي لدول الخليج. 0. الــشريف، محمـــد أحمـــد ( T . . Y).

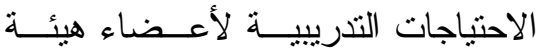
التدريس بجاكعة الطائف. در اسات فـي

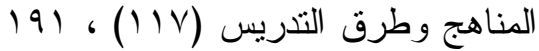
-

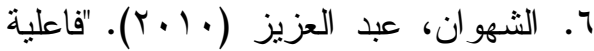
الدورات التدريبية للمشرفين التربويين و مديري المــدارس مــن وجهـــة نظــر المت لـدربين ". مجلــة رابطـــة التربيـــة الحديثة، (V) r (V - rON V. الطعاني، حسن أحمد (9 . . . . . التدريب مفهومه وفعالياته في بنــاء البـــر امج

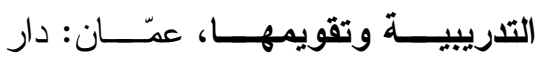
الثروق

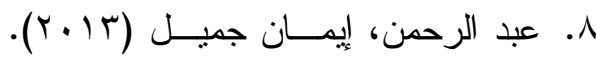
"درجة فاعلية أساليب بـــر امج التتميــة

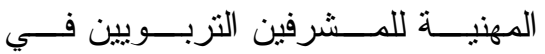
وز ارة التربية و التعليم الأردنيــة مــن وجهة نظر المشرفين التزبوبين"، مجلــة دراسات العلوم التربوية، ، ع (1)، بك .07 -
و المنجز ات التعليمية للطلبة وكل ضمن دوره فيما يتعلق بالمجـــالات القياديـــة

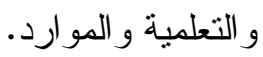
r- مقارنة أداء المديرين للعام الذي تدربوا فيه مع الأعو ام السابقة، والإطلاع على مدى النطور في المهار ات و الإمكانات

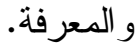
ع- استسقاء لردود أفعال العاملين وشركاء النجاح و أولياء الأمور للتعــرف إلـى التطور الذي حصل عليه المديرين بعد الالتحاق بالبر امج التدريبية، و التطـــور

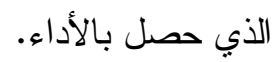

\section{قائمة المراجع}

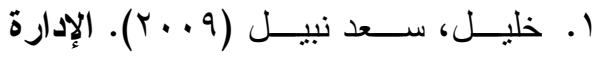
المدرسية الحديثة. القاهرة: دار الفجـر

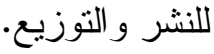

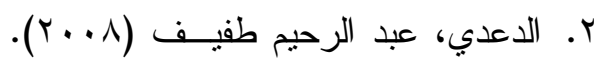
درجة ملاعمة تدريب مديري المدارس في الإدارة المدرسية بجامعة أم القزى

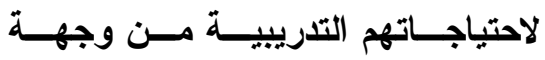
نظرهم. (رسالة ماجستير غير منشورة)، جامعة أم القرى، مكة المكرمة، المملكة العربية السعودية. r. الــسلمي، منـــصور نفيـــع (Y I (Y). الاحتياجات التدريبية لمديري المدارس الابتدائية بمدينة مكة المكرمة في ضوء متطلبات الإدارة الإكترونية. (رســالة 


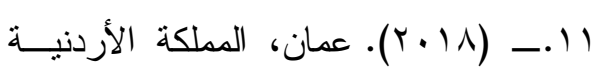

9. المر ايات، سفانة و القضاة، محمد أمــين

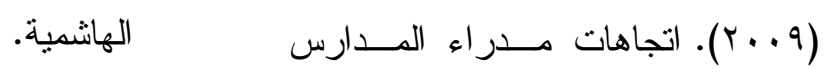

12. Collins, D. B, \& Holton E. F.

الثانوية الحكومية و المشرفين التربــويين (2004). The Effectiveness of Managerial Leadership

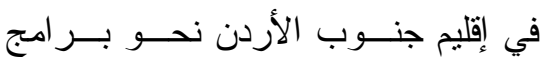
Development Programs: A Meta - Analysis of Studies. Human Resources Development Quarterly, 15 (2) $217-248$.

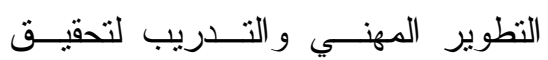
الاقتــــاد المعرفــي، مجلـــة العلــوم الإنسانية، العدد (r §) هو لندا.

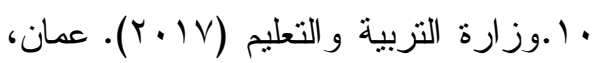
المملكة الأردنية الهاشمية. 